\title{
A hybrid power system based on fuel cell, photovoltaic source and supercapacitor
}

\author{
Seydali Ferahtia ${ }^{1}$ (D) Ali Djerioui ${ }^{2,3} \cdot$ Samir Zeghlache ${ }^{1} \cdot$ Azeddine Houari $^{4}$
}

Received: 27 October 2019 / Accepted: 7 April 2020 / Published online: 20 April 2020

(C) The Author(s) $2020 \quad$ OPEN

\begin{abstract}
In this study, we present an ameliorated power management method for dc microgrid. The importance of exploiting renewable energy has long been a controversial topic, and due to the advantages of DC over the AC type, a typical DC islanded micro-grid has been proposed in this paper. This typical microgrid is composed of two sources: fuel cell (FC), solar cell (PV) and one storage element [supercapacitor (SC)]. Here, we aimed to provide a management strategy that guarantees optimized bus voltage with arranged power-sharing between the sources. This proposed management aims to provide high-quality energy to the load under different loading conditions with variable solar irradiance, taking into account the FC state. Due to the slow dynamics of the FC, the SC was equipped to supply the transient period. A management algorithm is implemented to hold the $D C$ bus voltage stable against the load variations. The management controller is based on differential flatness approach to generate the references. The DC bus is regulated by the SC energy; to reduce the fluctuations in the DC bus voltage, The PI controller is implemented. This proposed strategy reduces the voltage ripple in the DC bus. Moreover, it provides permanent supplying to the load with smooth behaviour over the sudden changes in the demand as depicted in the simulation results. Our study revealed that this proposed manager can be used for this kind of grids easily.
\end{abstract}

Keywords Fuel cell (FC) · Supercapacitor (SC) · Energy management system (EMS) · DC microgrid · Flatness

\section{Introduction}

Currently, with the enormous demand for electricity, the research focus on integrating multiple power sources, such as oil, coal, nuclear or renewable energy. With the urgent necessity to balance fossil fuel depletion and reduce greenhouse gas emissions, the world is going towards on clean and efficient power sources, such as renewable (Photovoltaic, wind, biomass etc.) or fuel cells.

Fuel cell (FC) known as a high specific energy source, it is one of the possible alternative power sources for the future. Because it's efficiency, reliably and high power density [1], the FCs are a highly acceptable eco-friendly source for microgrids [2,3]. Microgrids based on fuel-cells are getting more attractive, as a result of the combination of the fuel-cell technology with microgrids, which serve a mutual task. Collaboratively, it meets current energy demand at a competitive cost, extremely reliable, clean, quiet, contained, modular and scalable.

Fuel cell installations worldwide are expected to increase more than tenfold, from the $262 \mathrm{MW}$ installed in 2016 to more than $3000 \mathrm{MW}$ after nine years. This would put the market for new fixed fuel cells at $\$ 16.2$ billion in 2025, according to Navigant Research [4]. It is wildly

Seydali Ferahtia, sidali.ferahtia@univ-msila.dz; $\bowtie$ Ali Djerioui, ali.djerioui@univ-msila.dz; Samir Zeghlache, samir.zeghlache@univ-msila.dz; Azeddine Houari, Azeddine.Houari@univ-nantes.fr | ${ }^{1}$ Lobartoire d'Analyse des Signiaux et Systemes, Department of Electrical Engineering, University of Msila, Msila, Algeria. ${ }^{2}$ IREENA Laboratory, University of Nantes, Nantes, France. ${ }^{3}$ Lobartoire de Génie Electrique, Department of Electrical Engineering, University of Msila, Msila, Algeria. ${ }^{4}$ IREENA Laboratory, Department of Industrial Engineering, University of Nantes, Nantes, France. 
intercorporate with other sources under the management controller, such as [5] which aims to reduce the fuel consumption based on an advanced manager.

According to the research in the literature [6-8], the time constant is depended on the temperature and the injection system (compressor, valves and the hydrogen reformer). As a consequence, fast change in the demand will cause temporarily a drop voltage (stack starvation phenomenon) $[9,10]$. To avoid the drop voltage and supply the trainset period, the system must have at least one auxiliary source (storage device) forming a hybrid power system. Thus, to use the FC, it's recommended to employ a current control loop to prohibit the overloads and improve its performance.

It is well known that if several DGs are deployed in a power grid, they will cause problems such as increasing voltage and instability [11]. These problems may damage some sensitive electrical loads.

To solve these problems, a powerful management algorithm has to be applied to ensure stable DC bus voltage against the environmental variations (demand or weather conditions).

Concerning the energy storage system, by comparing the power characteristics of the batteries and supercapacitors, the charge efficiency is higher for the SC than the battery (95\% for the SC and 50\% for the battery) [12]. Furthermore, the batteries' main disadvantage is a slowcharging time, constrained by a charge current [13]. On the other hand, the supercapacitors can be charged in a short period depending on the charge current (power) obtainable. More beneficial, unlike batteries, supercapacitors can endure a very high number of charge/discharge cycles without degradation (or visually unlimited cycles). Thus, the supercapacitors have high power density, long lifetime and faster dynamics than the batteries [14], this comparison proves that the supercapacitor is the most suitable over the battery.

Moreover, renewable energy sources are gaining more attention. One of these eco-friend sources is solar energy. It can be converted directly to electricity by the solar panels or concentrated solar power technology based on its thermal energy [15-17].

Conserving the solar panels, they can be integrated into the microgrid beside the other sources, such as wind or diesel generators [18-20]. It has been wildly used for serval application such as agriculture [21]. However, due to their intermittent production, cause a mismatch between supply and demand for power, and may affect the grid stability and reliability. Many studies have been done to improve the energy management system against this drawback. The combination between PV, FC and SC for energy production with short and long-term storage capacity is studied in [22]. PV/FC/battery two-level strategy for energy management is proposed in [23]. In [24], the proposed control algorithm is based on flatness approach; it provides stable operating for all the sources. Although, the fuel consumption is an important indicator for the management system. For this purpose, the fuel consumption optimizer is proposed in this paper.

In this paper, a hybrid power system consisting of $\mathrm{PV}$, FC and SC is studied. This hybrid system is controlled by an algorithm based on PI-flatness approach. The paper is structured as: Section I is the introduction. In Section II, the structure of the proposed hybrid power system, including the mathematical model. Then, Section III presents the control algorithm. Next, simulation results are explained in Section IV. Finally, the paper ends with the conclusion in Section V.

\section{Hybrid system structure}

\subsection{System configuration}

The proposed typical system consists of a 5 parallel solar panels 2 series (Soltech model-245Wh), fuel cell (PEMFC$6 \mathrm{KW}-45 \mathrm{VDC}$ ) and a supercapacitor (80F-48VDC). They are connected to the DC bus via DC/DC converters further control the power-sharing and to stabilize the DC bus voltage $(120 \mathrm{~V})$. This microgrid has been designed to operate in islanded (off-grid). The performance is inspected by imposing deferent loads. On the whole, the FC stack and the PV source provide power to satisfy the demand power needs. The supercapacitor delivers the power to stabilize the $D C$ bus voltage during the transient periods.

The structure of the studied system with the power electronic converters are illustrated in Fig. 1 which shows

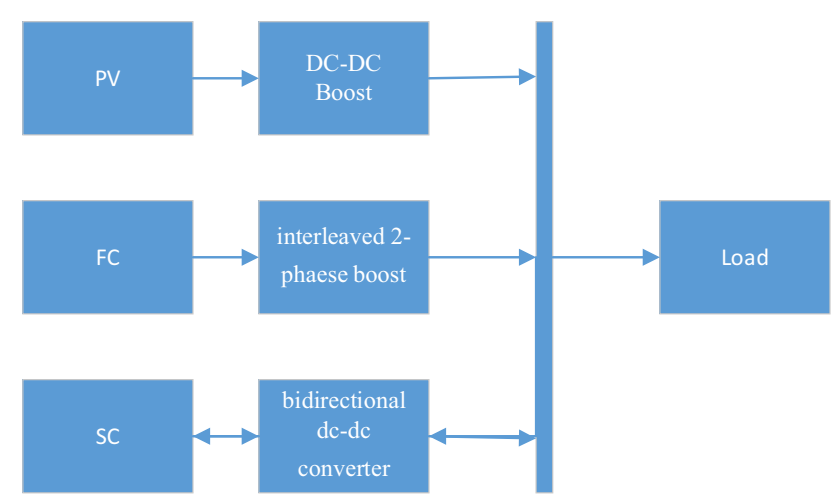

Fig. 1 The proposed hybrid system with PV and FC as primary sources, and supercapacitor as an auxiliary source connected in parallel with the load side. Where the PV is connected via a boost converter, the FC is connected by an interleaved two-phase boost converter and the SC is connected via a bidirectional DC-DC converter 
that all the converters are connected in parallel. Twophases parallel boost converters used to control the FC stake, this converter is controlled with interleaving technic, thus, the power quality is improved [25]. A boost converter is utilized to control the produced power by the solar cell. The supercapacitor is always connected to the DC bus by a bidirectional boost converter, this structure allows to charge or discharge the supercapacitor. Moreover, to ensure safe operating and soft dynamics, all the converters are controlled by the current regulation loop. This supercapacitor control loop is supposed much faster than the other control loops. The energy management system generates tow references signals: $i_{F C_{C} R E F}$ and $i_{S C_{\_} R E F}$. The merits of this algorithm are devoted to finding the optimal FC power correction effort through the management of the system stockers' energy, namely the energy of the DC-bus and SCs.

In this studied system, there are two energy variables to be controlled, the DC bus energy and the supercapacitor energy.

\subsection{FC modelling}

The FC is an electrochemical source, which converts the energy of the fuel reaction to electricity, from $[26,27]$, the production depends only by the availability of the fuel as explained following expression

$\mathrm{H}_{2}+1 / 2 \mathrm{O}_{2} \rightarrow \mathrm{H}_{2} \mathrm{O}+$ Heat + Electricity

The fuel cell stack can be considered as controlled current sources. The model provided by Sim Power System of MATLAB/SIMULINK is employed in this study. Figure 2 shows the equivalent circuit of the studied model. Where the V-I and P-I characteristics curves are depicted in Fig. 3.

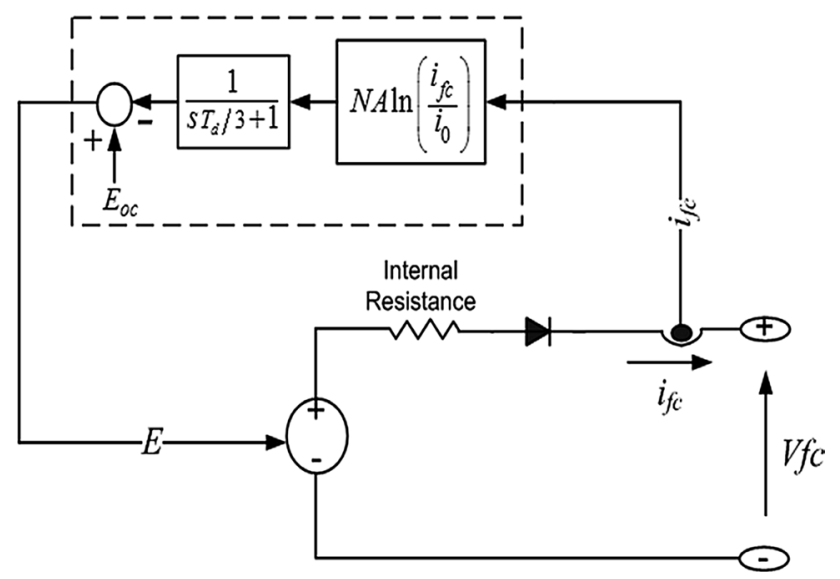

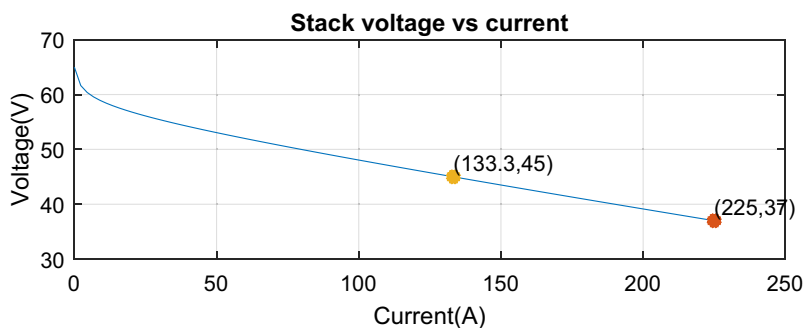

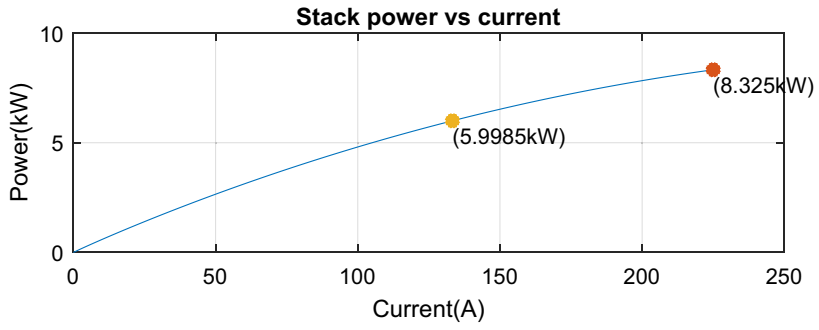

Fig. 3 I-V and P-V characteristics graphs of the proposed Fuel cell

To operate an $\mathrm{FC}$, its constraints have to be respected such as:

- The generated power shall be held within an interval (max and 0 )

- The FC current slope should be limited to a max value to avoid the FC stack from a fuel starvation phenomenon.

- The switching frequency of the current shall be higher than $1.25 \mathrm{kHz}$ and the FC ripple current shall be less than about $5 \%$ of the rated value to assure a small impact on the FC conditions [28].

The parameters are obtained from $[29,30]$ where

$E_{O C}=k_{C} E_{n}$

$i_{O}=\frac{z F R\left(P_{\mathrm{H}_{2}}+P_{\mathrm{O}_{2}}\right)}{R h} e^{-\frac{\Delta G}{R T}}$

$A=\frac{R T}{Z \alpha F}$

And the FC model parameters are given in Table 1 [29].

\subsection{PV modelling}

The solar energy is converted to electricity by using photovoltaic modules. These modules can be connected in series or parallel depending on the desired voltage and current. From [31,32], the output current is defended as

Fig. 2 The equivalent circuit of the FC stack 
Table 1 Model parameters

\begin{tabular}{llll}
\hline $\mathrm{R}$ & $8.3745 \mathrm{j} /(\mathrm{mol} \mathrm{K})$ & $\mathrm{z}$ & Number of moving electrons \\
$\mathrm{F}$ & $96485 \mathrm{As} / \mathrm{mol}$ & $\mathrm{k}$ & Boltzmann's constant $1.38 \times 10^{-23} \mathrm{~J} / \mathrm{K}$ \\
$E_{n}$ & Nernst voltage $(\mathrm{V})$ & $\mathrm{h}$ & Plank's constant $6.626 \times 10^{-34} \mathrm{Js}$ \\
$\mathrm{a}$ & Charge transfer coefficient & $\Delta \mathrm{G}$ & Size of the activation barrier \\
$P_{\mathrm{H}_{2}}$ & Partial presser of hydrogen (atm) & $\mathrm{T}$ & Temperature $(\mathrm{K})$ \\
$P_{\mathrm{O}_{2}}$ & Partial presser of oxygen (atm) & $k_{\mathrm{C}}$ & Voltage constant at nominal conditions \\
\hline
\end{tabular}

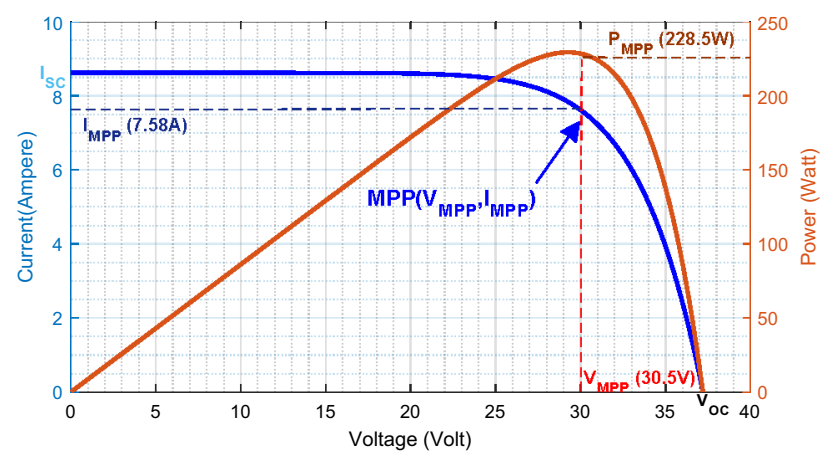

Fig. $4 \mathrm{I}-\mathrm{V}$ and $\mathrm{P}-\mathrm{V}$ characteristics graphs of the proposed solar panel for $\mathrm{T}=25^{\circ}$ and $\mathrm{rad}=1000 \mathrm{~W} / \mathrm{m}^{2}$

$I=I_{p h}-I_{0}\left[e^{\frac{q\left(\left(R_{S}\right)\right.}{K_{B} T a}}-1\right]-\frac{\left(V+I R_{S}\right)}{R_{P}}$

where $\mathrm{q}$ is the charge of the electron and $K_{B}$ is the Boltzmann constant. The photocurrent depends on the variation of the radiance and temperature as [31]

$I_{p h}=\left[I_{S C}+K\left(T-T_{\text {ref }}\right)\right] \lambda$

where, $I_{S C}$ is the short circuit current, $T$ and $T_{\text {ref }}$ represents the actual and reference temperature, $\mathrm{K}$ is the co-efficient of temperature at $I_{S C}$ and $\lambda$ is the value of radiance in $\mathrm{kW} /$ $\mathrm{m} 2$. Hence, the expression of current provided by the PV array in the function of the number of modules in series $\left(N_{S}\right)$ and parallel $\left(N_{P}\right)$, photocurrent $\left(I_{p h}\right)$, and saturation current $\left(I_{0}\right)$, ideality factor $(\mathrm{a})$, series $\left(R_{S}\right)$ and parallel $\left(R_{P}\right)$ resistances can be expressed as

$$
\begin{gathered}
I=N_{P} I_{p h}-N_{P} I_{0}\left[e^{\frac{V+l\left(N_{S} N_{P}\right) R_{S}}{N_{S} a V_{t h}}}-1\right] \\
-\frac{V+I\left(\frac{N_{S}}{N_{P}}\right) R_{S}}{\left(\frac{N_{S}}{N_{P}}\right) R_{P}}
\end{gathered}
$$

Based on the $\mathrm{P}-\mathrm{V}$ and the $\mathrm{I}-\mathrm{V}$ characteristics displayed in Fig. 4. The MPPT algorithm extracts the power at its maximum point.

From this figure, it's clear that there is an operating point (Vmpp-Impp) represent the maximum power

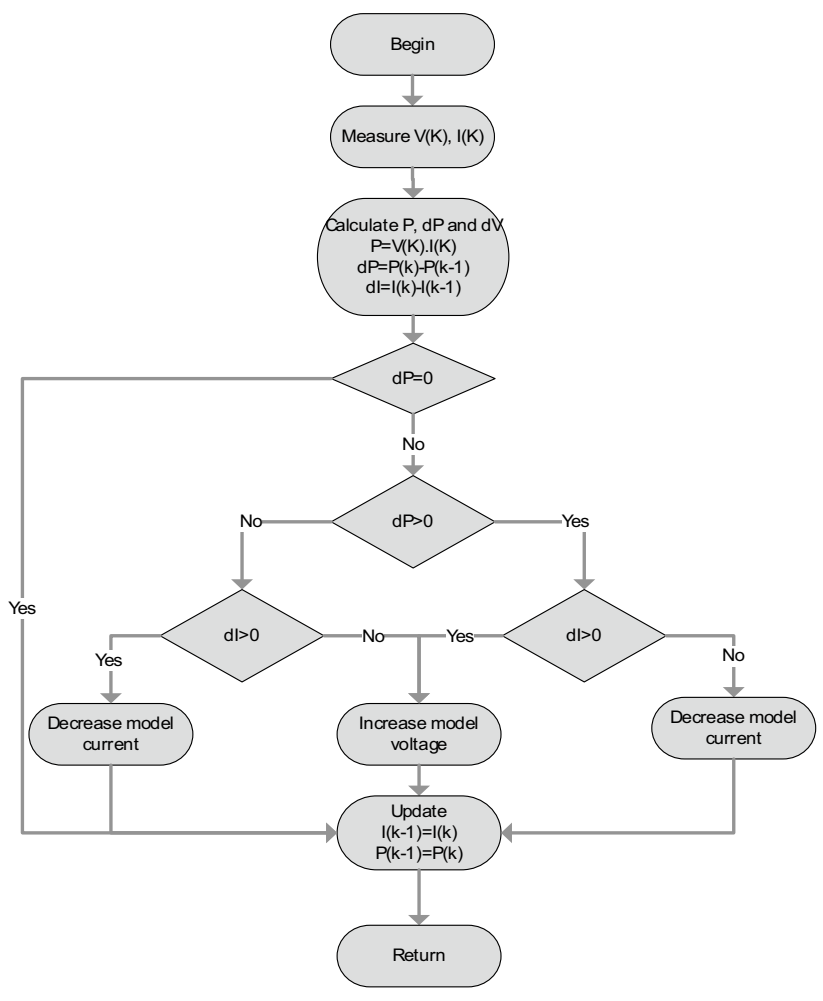

Fig. 5 Flow chart of perturbation and observation (P\&O) technic

obtained from the PV. To achieve this point a DC-DC converter controlled by MPPT technic is employed.

P\&O (Perturbation \& Observation) technic [33, 34] is used in this paper, it has been widely used in the real application. It moves the operating point toward the MPP periodically increasing or decreasing the PV array variable. Thus, the operating point oscillates around the MPP. The principal steps are given in the flowchart in Fig. 5.

\subsection{Supercapacitor modelling}

Supercapacitors (SCs) reflect electrical energy storage devices that offer high power density, fast charging times, high cycles and long service life. It mostly used in fast energy-storage applications, where fast dynamic charging and high-current discharging processes are needed [35]. The used model in this paper is based on Matlab/Simulink model 
which illustrated in Fig. 6. Where all the model parameters are extracted from the Matlab mode (2017b).

\subsection{Load modelling}

A dynamic load profile is proposed where the required power have the behaviour of a controlled current source where the load power equals to

$P_{\text {load }}=i_{\text {load }} \cdot v_{\text {bus }}$

\subsection{System behaviour modelling}

The objective of the management system is to maintain the $D C$ bus voltage at the reference voltage $(120 \mathrm{~V})$, for this purpose the supercapacitor control the DC bus energy by transmitting the energy to (discharge) or from (charge) the DC bus. According to [36], the capacitive energy is given as

$E_{S C}=1 / 2 C_{S C} v_{S C}^{2}$

Due to the capacitance on the DC bus, the electromagnetic energy on a common link can be written as

$E_{\text {bus }}=1 / 2 C_{\text {bus }} v_{\text {bus }}^{2}$

Following Fig. 1, the $\mathrm{DC}$ bus capacitive energy $E_{\text {bus }}$ is given in function of $P_{F C_{o}}, P_{P V_{o}}, P_{S C_{o}}$ and $P_{\text {load }}$ it can be written as

$\dot{E}_{\text {bus }}=P_{F C_{o}}+P_{P V_{o}}+P_{S C_{o}}-P_{\text {load }}$

where $P_{F C_{o}}, P_{P V_{o}}$ and $P_{S C_{o}}$ are the delivered power from the sources including the converter losses

$P_{F C_{o}}=P_{F C}-r_{F C}\left(P_{F C} / v_{F C}\right)^{2}$

$P_{P V_{o}}=P_{P V}-r_{F C}\left(P_{P V} / v_{P V}\right)^{2}$
$P_{S C_{o}}=P_{S C}-r_{S C}\left(P_{S C} / v_{S C}\right)^{2}$

$r_{F C}$ Static losses in the FC converter, $r_{P V}$ Static losses in the PV converter, and $r_{S C}$ Static losses in the SC converter.

Supposing that $\mathrm{FC}$ and $\mathrm{SC}$ follow their reference values, the power references can write as

$P_{F C}^{r e f}=P_{F C}=v_{F C} i_{F C}$

$P_{S C}^{r e f}=P_{S C}=v_{S C} i_{S C}$

The total electromagnetic stored in the DC bus capacitor and the supercapacitor given as

$E_{T}=E_{\text {bus }}+E_{S C}$

where the load power can be expressed from Eq. (9) as

$P_{\text {load }}=\sqrt{2 E_{\text {bus }} / C_{\text {bus }}} \cdot i_{\text {load }}$

\section{Control strategy}

In this proposed system, the PV panel operates at the maximum power point tracking (MPPT); P\&O algorithm illustrated in Fig. 2 applied to achieve the MPPT [33]. Both the $\mathrm{PV}$ and the $\mathrm{FC}$ stack are generators supplying the demand. The total power generated can be written as

$P_{G e n}=P_{P V_{o}}+P_{F C_{0}}$

By replacing in Eq. (11)

$\dot{E}_{\text {bus }}=P_{\text {Gen }}+P_{S C_{\text {o. }}}-P_{\text {load }}$

This generated power must satisfy the load demand and charge the storage device similarly. While the PV provides its maximum power to the load, the difference between the required power and the offered by the PV is supplied by the FC stack.
Fig. 6 The equivalent circuit of the SC module

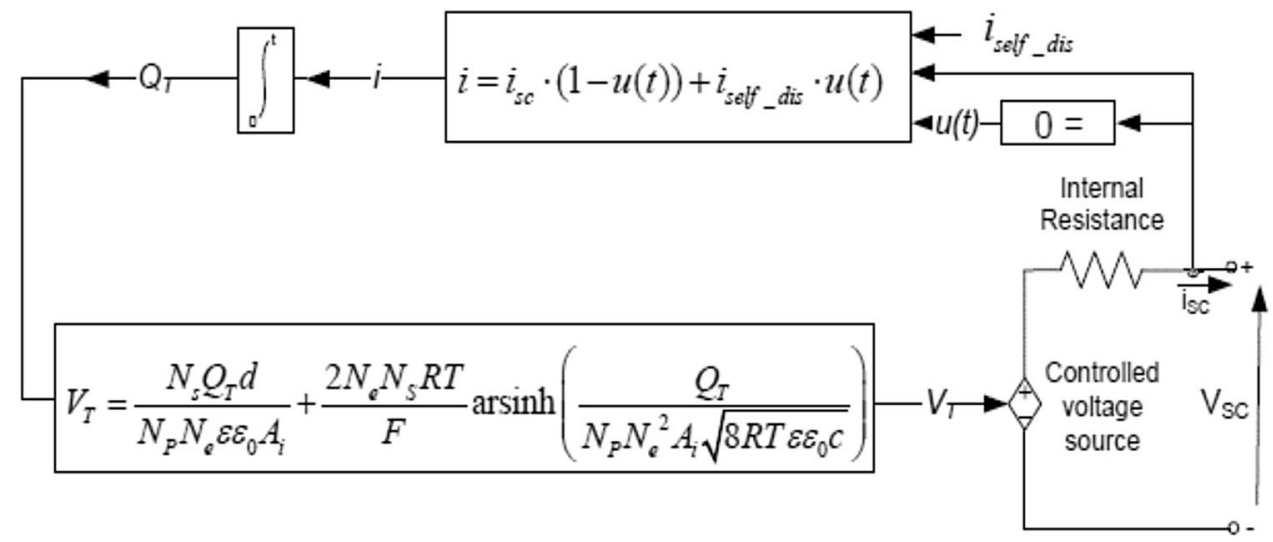

SN Applied Sciences 
From Eq. (19), the total generated power can be expressed as

$P_{\text {Gen }}=\dot{E}_{\text {bus }}+P_{\text {load }}-P_{S C_{\text {o. }}}$

The generated power is the sum of the PV and the FC power. Mainly, the generated power is depended on the PV power, as mentioned before, the deference on power is compensated by the FC power. Hence, the power reference of the FC stack is given as

$P_{F C}^{r e f}=P_{G e n}-P_{P V_{0}}$

\subsection{Principle of differential flatness theory}

Because of the non-linearity of the system, the control may be more complex. Nevertheless, the reduced-order model obtained by applying the differential flatness theory on the non-linear system. This alternative model allows characterizing the trajectories including their dynamics. According to Fliess et al. [37, 38], the system can be considered flat is the flat output $\boldsymbol{y}$ can give by

$y=\phi\left(x, u, \dot{u}, \ldots . ., u^{(\alpha)}\right)$

where $\boldsymbol{x}$ is the stat variables and $\boldsymbol{u}$ the control input variables, they can be written as

$x=\varphi\left(y, \dot{y}, \ldots . ., y^{(\beta)}\right)$

$u=\psi\left(y, \dot{y}, \ldots . ., y^{(\beta+1)}\right)$

With $\varphi(),. \psi(),. \phi($.$) are the smooth mapping functions,$ The latter notation generalizes to yield the notation $y^{\beta+1}$ for the $(\beta+1)$ th derivative of $y$. Similarly, $a$ is a finite number of there derivative, and $\operatorname{rank}(\phi)=m, \operatorname{rank}(\psi)=m$, and $\operatorname{rank}(\varphi)=n$.

\subsection{The flatness of the power system}

In the studied system, the flat model represented by its flat output $y=\left[\begin{array}{ll}y_{1} & y_{2}\end{array}\right]$, the control variable $u=\left[\begin{array}{ll}u_{1} & u_{2}\end{array}\right]^{t}$, and the stat variables $x=\left[\begin{array}{ll}x_{1} & x_{2}\end{array}\right]^{t}$, where:

$y=\left[\begin{array}{l}E_{\text {bus }} \\ E_{T}\end{array}\right], u=\left[\begin{array}{l}P_{S C}^{\text {ref }} \\ P_{F C}^{\text {ref }}\end{array}\right], x=\left[\begin{array}{l}v_{\text {bus }} \\ v_{S C}\end{array}\right]$

The state variables, from Eq. (9) $v_{\text {bus }}\left(x_{1}\right)$ can be written as

$x_{1}=\sqrt{2 y_{1} / C_{\text {bus }}}=\phi_{1}\left(y_{1}\right)$

From Eq. (10) $v_{S C}\left(x_{2}\right)$ is written as $x_{2}=\sqrt{2\left(y_{2}-y_{1}\right) / C_{S C}}=\phi_{2}\left(y_{1}, y_{2}\right)$

The first input control variables, from Eqs. (10, 11, 13 and 17) the SC power reference can write as

$u_{1}=2 P_{S C \max }\left[1-\sqrt{1-\sqrt{\frac{\dot{y}_{1}+\sqrt{\frac{2 y_{1}}{C_{\text {bus }}}} \cdot i_{\text {load }}-P_{\text {Gen }}}{P_{S C \max }}}}\right]$

$$
=\psi_{1}\left(y_{1}, \dot{y}_{1}\right)=P_{S C_{\text {ref }}}
$$

$P_{S C \max }=v_{S C}^{2} / 4 r_{S C}$

Defining $P_{S C \max }$ as the limited maximum power from the SC converter.

For the second input control, the FC power reference is calculated from Eqs. $(10,11,16,17$ and 20)

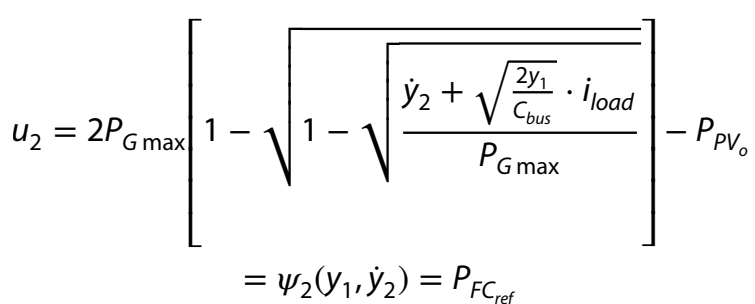

$P_{G \text { max }}=P_{F C \max }+P_{P V \text { max }}$

where $P_{G \max }$ the limited maximum power from the sources, $\mathrm{PV}$ and FC converters.

In the ideal model where the losses in the converters are neglected, the input control variables can be written as

$u_{1}=\dot{y}_{1}+\sqrt{2 y_{1 / C_{\text {bus }}}} \cdot i_{\text {load }}-P_{\text {Gen }}=\psi_{1}\left(y_{1}, \dot{y}_{1}\right)$

$u_{2}=\dot{y}_{2}+\sqrt{2 y_{1} / C_{\text {bus }}} \cdot i_{\text {load }}-P_{P V_{o}}=\psi_{2}\left(y_{1}, \dot{y}_{2}\right)$

Thus, from Eqs. (27-30)

$x=\left[\begin{array}{ll}\phi\left(y_{1}\right) & \phi\left(y_{1}, y_{2}\right)\end{array}\right]^{t}, u=\left[\begin{array}{ll}\phi\left(y_{1}, \dot{y}_{1}\right) & \phi\left(y_{1}, \dot{y}_{2}\right)\end{array}\right]^{t}$

As a result, the proposed reduced-order model can be considered as a flat system.

\subsection{DC bus voltage stabilisation}

Above all, the most important variable to regulate is to regulate the flat output $y_{1}=E_{\text {bus }}$. To ensure the control of this flat variable a PI classical control low is applied. Supposing that the $\mathrm{SC}$ control loop is much faster than the FC 
and the PV control loops [36], the DC bus power expressed in Eq. (11) can be written approximately as

$\dot{E}_{\text {bus }}=P_{S C_{o}}$

The transfer function is a pure integrator. Based on [32], a $\mathrm{PI}$ regulator is proposed to regulate the $\mathrm{DC}$ bus energy. Knowing that $y_{1}^{\text {ref }}=E_{\text {bus }}^{\text {ref }}$ as follow

$\dot{y}_{1}=\frac{1}{s}\left(K_{p}+\frac{K_{i}}{s}\right)\left(y_{1}-y_{1} \_r e f\right)$

$K_{p}=2 \cdot \zeta \cdot \omega_{n}$

$K_{i}=\omega_{n}^{2}$

where $\omega_{n}$ the natural frequency, $\zeta$ the dumping factor.

To generate the current reference for the FC converter, the power reference generated by the inverse dynamic in Eq. (29) is divided by the measured supercapacitor voltage. The control scheme of the DC bus voltage is illustrated in Fig. 7.

\subsection{SC voltage loop}

The SC has enormous capacitive energy over the DC bus capacitance, but with slower dynamic. The control loop of the SC energy depends on the regulation of the total electromagnetic energy. The control low as used in [36] is written as $\left(\dot{y}_{2}-\dot{y}_{2 R E F}\right)+K_{S C}\left(y_{2}-y_{2 R E F}\right)=0$

Replacing in Eq. (29), the input control low

$$
u_{2}=2 P_{G \max }\left[1-\sqrt{1-\sqrt{\frac{\dot{y}_{2}^{\text {ref }}+K_{S C}\left(y_{2}^{\text {ref }}-y_{2}\right)+\sqrt{\frac{2 y_{1}}{C_{\text {bus }}}} \cdot i_{\text {load }}}{P_{G \text { max }}}}}\right]-P_{P V_{o}}
$$

To ensure safe operating for the FC stack, the transient power must be limited. Thus, a low-pass filter is employed to ensure the desired trajectory planning as

$\frac{P_{F C_{f}}^{r e f}}{P_{F C}^{r e f}}=\frac{1}{\tau s+1}$

where $P_{F C}^{\text {ref }}$ the limited power reference and $\tau$ time constant. Figure 8 resume the control algorithm of the SC energy.

\section{System simulation}

The performance of the proposed EMS shall be validated by the simulation of the proposed typical DC microgrid. All sources are linked to a common DC bus, and the control system is used to maintain the voltage at its reference. After the designing of the control scheme. Simulation of the hybrid power system realized in Matlab/Simulink 2017.

The $\mathrm{DC}$ bus reference voltage is $120 \mathrm{~V}$. The demand will be varied to emulate the real environment behaviour, as

Fig. 7 The control scheme of DC bus energy

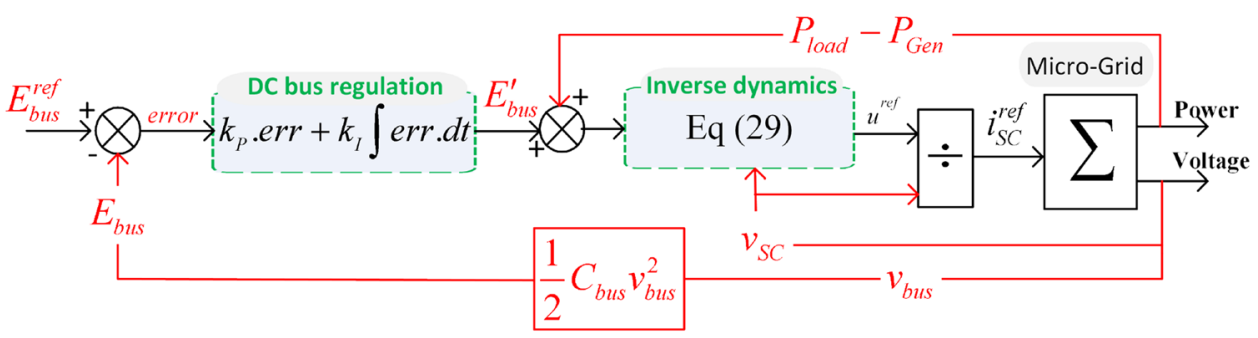

Fig. 8 The control scheme of supercapacitor energy

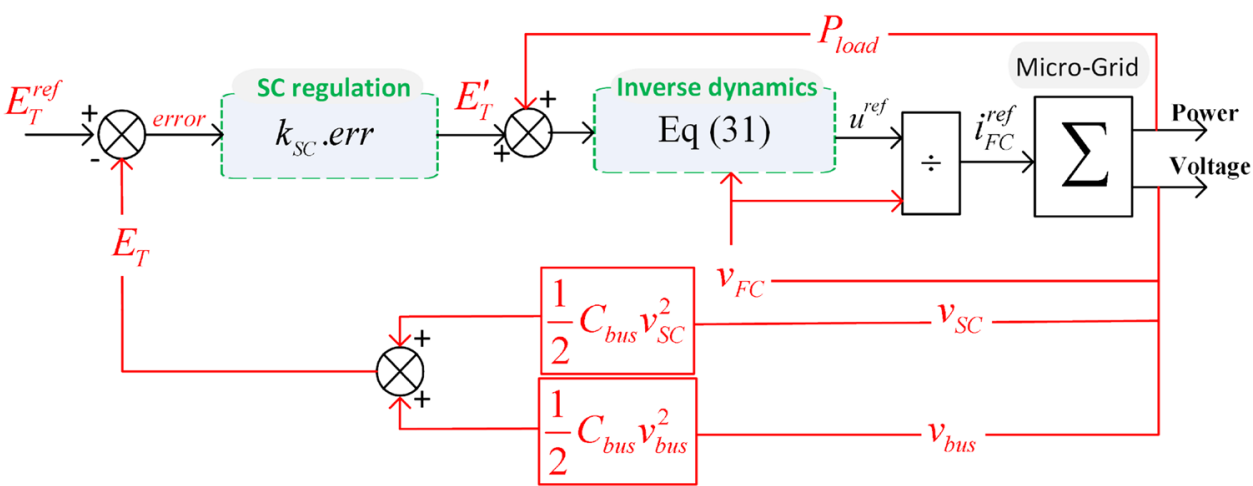


Table 2 System parameters

\begin{tabular}{llll}
\hline $\begin{array}{l}\text { Variable/param- } \\
\text { eter }\end{array}$ & Value & $\begin{array}{l}\text { Variable/param- } \\
\text { eter }\end{array}$ & Value \\
\hline$v_{\text {bus_REF }}$ & $120 \mathrm{v}$ & $v_{S C \_R E F}$ & $48 \mathrm{~V}$ \\
$C_{\text {bus }}$ & $1000 \mathrm{e}-5 \mathrm{~F}$ & $C_{S C}$ & $80 \mathrm{~F}$ \\
$k_{P}$ & 66 & $k_{S C}$ & 0.1 \\
$k_{l}$ & 3025 & $\tau$ & 0.5 \\
$r_{F C}$ & $0.1 \Omega$ & $r_{S C}$ & $0.1 \Omega$ \\
\hline
\end{tabular}

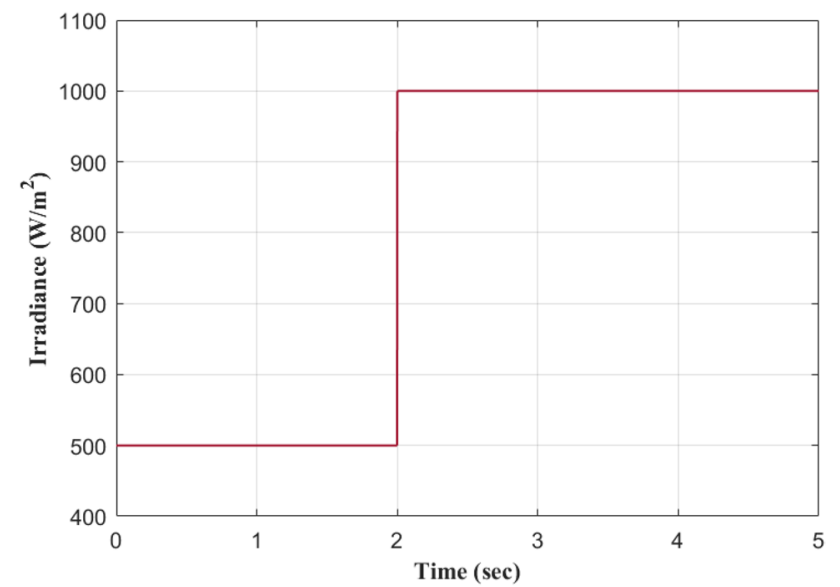

Fig. 9 The radiance profile

mentioned before, all the sources are connected to the DC bus via a power electronic converter. The parameters of the control loop are given in Table 2.

The radiance profile used in the simulation is presented in Fig. 9 while the temperature supposed fixe in $25^{\circ} \mathrm{C}$. A step in the radiance at the $2 \mathrm{nd} \mathrm{s}$ is imposed from 500 to $1000 \mathrm{~W} / \mathrm{m}^{2}$. Thus, the PV power will increase at this moment.

Figure 10 depicts the demanded power reference during the simulation time. It changed from 1.2 to $2.4 \mathrm{~kW}$ (Medium load, overload, temporary transition.).

To validate the proposed controller, a comparative study between the flat controller and a PI controller was realized. Figure 11 shows the DC bus voltage simulation results during $5 \mathrm{~s}$, the first curve in bleu using the proposed control algorithm when the second curve illustrates the Vbus using the PI controller.

From the results, the DC bus voltage using the proposed controller can provide better performance than offered by the PI controller. It offers faster response without overshot, low pics value and more robustness.

Figure 12 shows supercapacitor dynamics, the dynamics are faster using the proposed algorithm. During the load variations, the SC supplies the load demand until the generated power arrived its reference (both the PV and

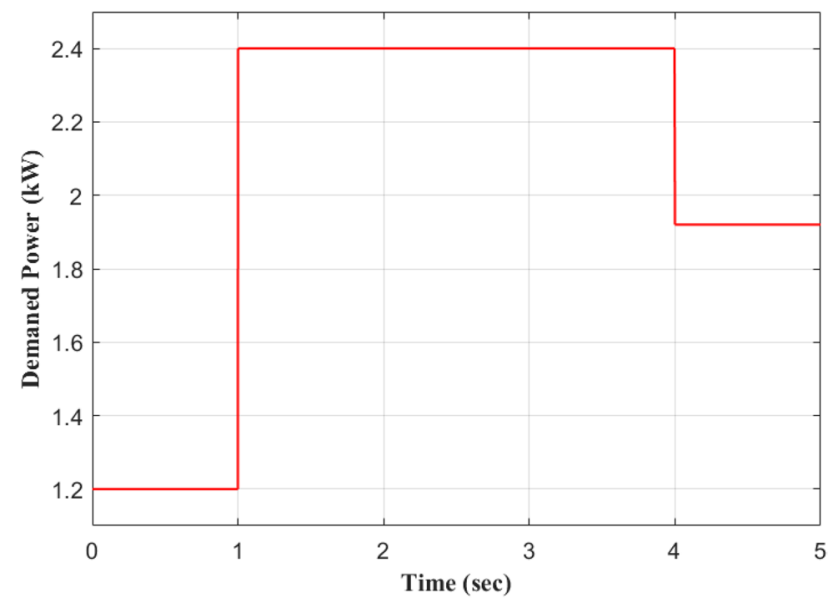

Fig. 10 The demanded power by the load

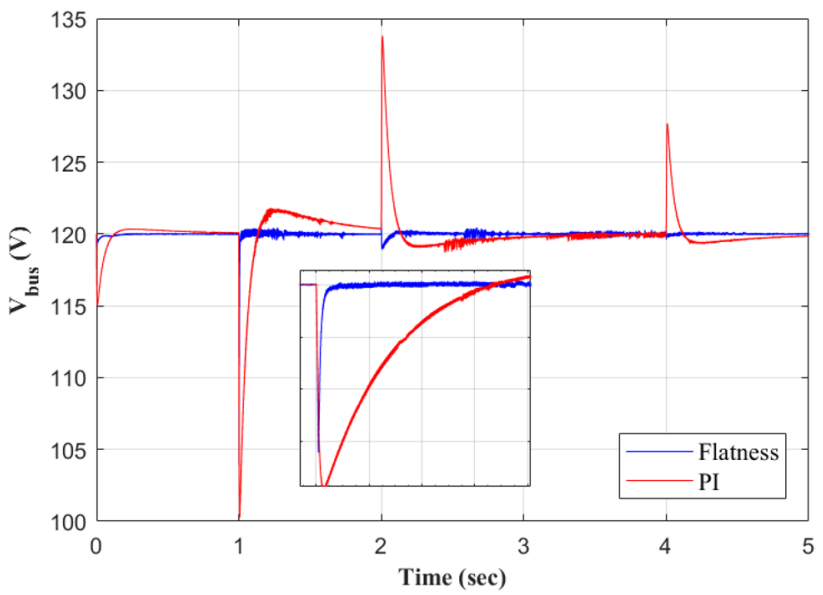

Fig. 11 DC bus voltage

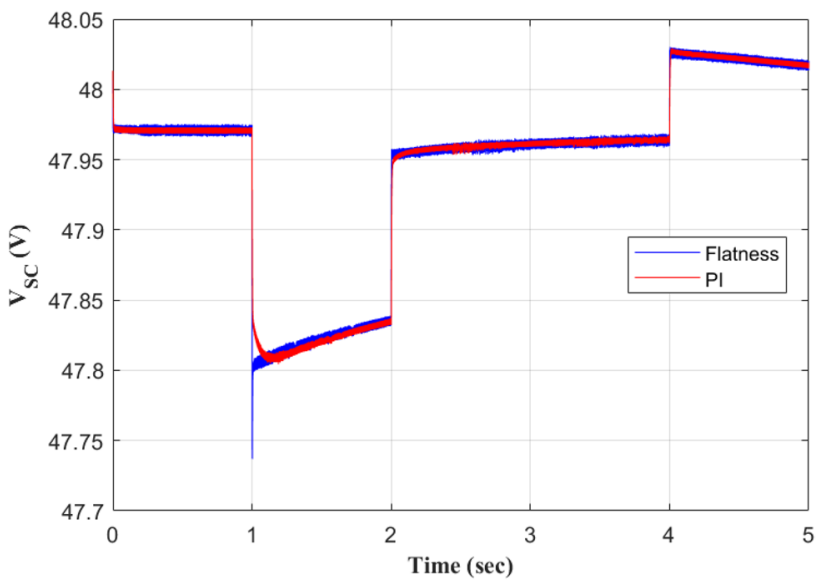

Fig. 12 SC power using both technics PI and flatness 
the FC). As a result, the stabilization of the $\mathrm{DC}$ bus voltage is improved.

Figure 13 displays power waveforms that are created during the simulation. The illustrations show the PV power, the FC power, the load power as well as the SC power.

In the beginning, the load power is relatively small $(1.2 \mathrm{~kW})$, whilst the PV power is smaller than the demanded (nearly $1 \mathrm{~kW}$ ); as a consequence, the FC stack begins supplying the needed power. The SC supplies almost all of the transient power, it remains decreases slowly because the steady-state load power is greater than the total generated power.

The load power at $\mathrm{t}=1 \mathrm{~s}$ increases (from 1.2 to $2.4 \mathrm{~kW}$ ). Following remarks are formulated:

- The SC supplies almost all of the transient phase load.

- At the same time, the FC power increases to $1.45 \mathrm{~kW}$ with limited dynamics.

At $\mathrm{t}=2 \mathrm{~s}$, the radiance rises, consequently, the PV power increases (to $1.84 \mathrm{~kW}$ ). The following notes will be taken:

- The SC absorbs the surplus of the bus energy.

- The FC power reference decrease (to $0.56 \mathrm{~kW}$ ) with limited power dynamics.

After $4 \mathrm{~s}$, the demand decreases to its lower value $(1.9 \mathrm{~kW})$, the FC stack power decrease with limited dynamics, and the transient period is regulated by the SC by absorbing the excess power.

Figure 14 represents the SC stat of charge, it explains the behaviour of the SC, it mainly discharges (supplies) with the step-up in the load or case of radiance diminution. Where it charges with the step down in the load or with augmentation of the radiance.

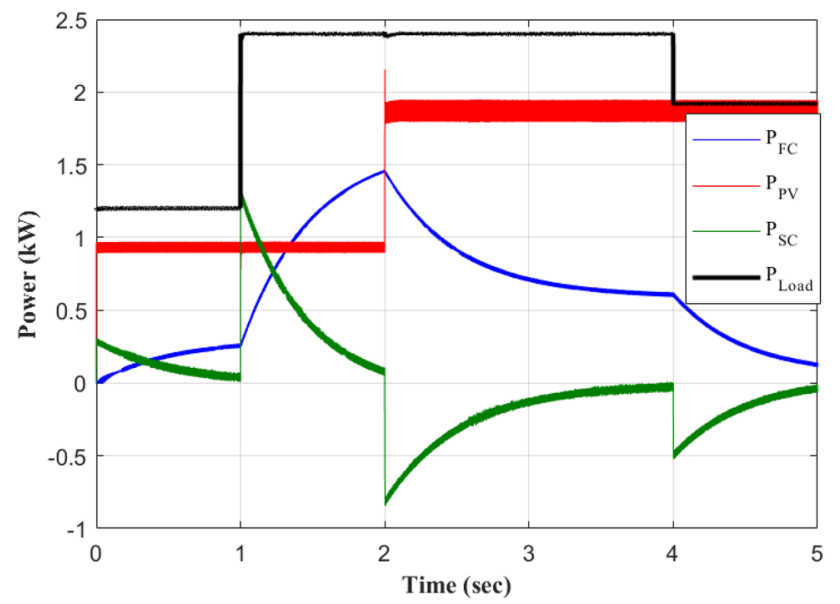

Fig. 13 Power curves of the load, the FC, the PV and the supercapacitor

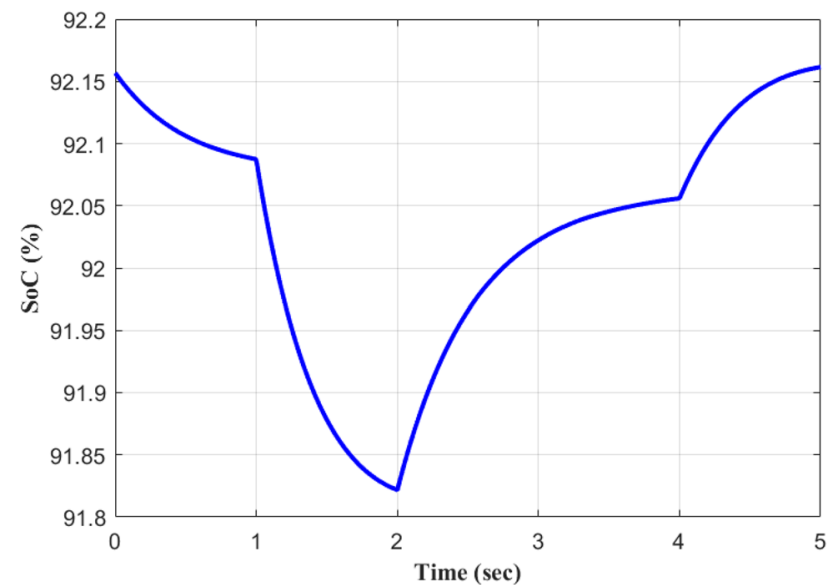

Fig. 14 The stat of charge (SoC) of the supercapacitor

The proposed algorithm performances are compared in the filter-based method [39]. It is shown that the proposed approach allows ensuring the requested power while it minimizes the solicitation on the stocker (SC). Therefore, the most important variable to regulate is to regulate the flat output. In contrast, the filter-based method acts only on the dynamic of the sources and the SC can experience wide change under variable loading conditions. This point in great importance in terms of the energy sizing of the SC.

Cbus conditions of selection:

As depicted in Fig. 15, the bus voltage depends also on the Cbus capacitance value, where different values were applied with different topologies (unique-parallel-series). The series montage is inappropriate for this application (low precision and high pic step). The parallel structure offers better behaviour (high stability) with small overshot and slower dynamic. Unique Cbus offers high performance with high capacitance value, thus it's suitable for sensitive applications such as EVs.

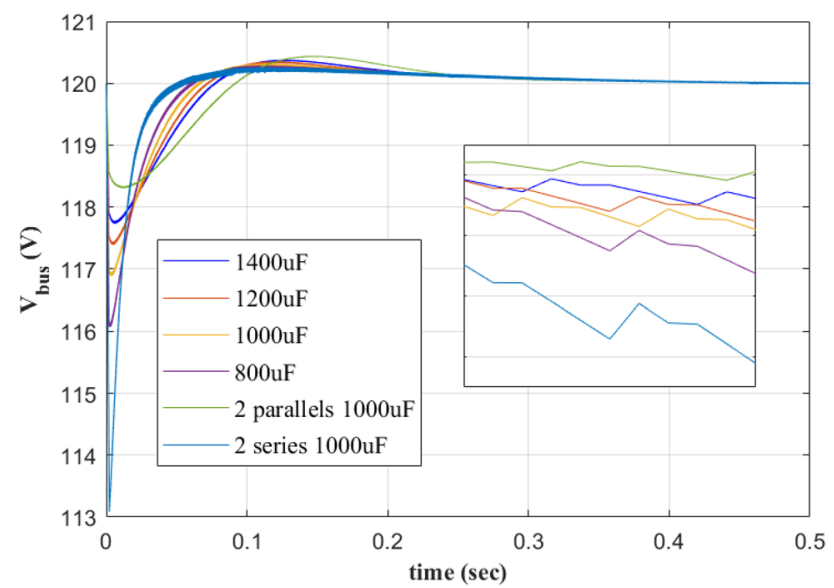

Fig. 15 Bus voltage with different Cbus values 


\section{Conclusion}

In conclusion, this study's main objective is to ensure stable DC bus voltage by providing an effective system for DC micro-grid powered by a fuel cell and solar panel, and the backup storage unit (SC). The parallel employment of $\mathrm{PV}$ and FC ensure to the load is sustainable suppling. The research focuses mostly stabilizing the DC bus voltage, moreover, employing the $\mathrm{FC}$, solar panel and SC in the energy management approach, taking into account the energetic properties of these sources such as its power and energy density and its dynamics. Nonlinear differential flatness strategy for DC microgrid based on a renewable source with a fuel cell provides excellent DC-link stabilization. The supercapacitor can move the load forward, regarding the characteristics of the main sources, by supplying a stronger power response to the load. During the important steps of the load, the supercapacitor offers the energy balance required during the transition of the load. Also, distributed power systems improve power quality and efficiency.

Acknowledgements This work was supported by the International WISE RFI Electronique program and FEDER fund.

\section{Compliance with ethical standards}

Conflict of interest The authors declare that they have no conflict of interest.

Open Access This article is licensed under a Creative Commons Attribution 4.0 International License, which permits use, sharing, adaptation, distribution and reproduction in any medium or format, as long as you give appropriate credit to the original author(s) and the source, provide a link to the Creative Commons licence, and indicate if changes were made. The images or other third party material in this article are included in the article's Creative Commons licence, unless indicated otherwise in a credit line to the material. If material is not included in the article's Creative Commons licence and your intended use is not permitted by statutory regulation or exceeds the permitted use, you will need to obtain permission directly from the copyright holder. To view a copy of this licence, visit http://creativecommons .org/licenses/by/4.0/.

\section{References}

1. Podder AK, Ahmed K, Roy NK, Biswas PC (2017) Design and simulation of an independent solar home system with battery backup. In: 4th international conference on advances in electrical engineering, ICAEE 2017, vol 2018 January, pp 427-431

2. Li Z (2019) A review of the applications of fuel cells in microgrids: opportunities and challenges. BMC Energy 1(2):1-23

3. Podder AK, Ahmed K, Roy NK, Habibullah M (2019) Design and simulation of a photovoltaic and fuel cell based micro-grid system. In: International conference on energy and power engineering: power for progress, ICEPE 2019

4. Obara S (2009) Fuel cell micro-grids. Power Syst 43:1-249
5. Djelailia O, Kelaiaia MS, Labar H, Necaibia S, Merad F (2019) Energy hybridization photovoltaic/diesel generator/pump storage hydroelectric management based on online optimal fuel consumption per kWh. Sustain Cities Soc 44:1-15

6. Corrêa JM, Farret FA, Popov VA, Simões MG (2005) Sensitivity analysis of the modeling parameters used in simulation of proton exchange membrane fuel cells. IEEE Trans Energy Convers 20(1):211-218

7. Corrêa JM, Farret FA, Canha LN, Simoes MG (2004) An electrochemical-based fuel-cell model suitable for electrical engineering automation approach. IEEE Trans Ind Electron 51(5):1103-1112

8. Zhu T, Shaw SR, Leeb SB (2006) Transient recognition control for hybrid fuel cell systems. IEEE Trans Energy Convers 21(1):195-201

9. Schmittinger W, Vahidi A (2008) A review of the main parameters influencing long-term performance and durability of PEM fuel cells. J Power Sources 180(1):1-14

10. Wu J et al (2008) A review of PEM fuel cell durability: degradation mechanisms and mitigation strategies. J Power Sources 184(1):104-119

11. Kakigano H, Miura Y, Ise T (2010) Low-voltage bipolar-type dc microgrid for super high quality distribution. IEEE Trans Power Electron 25(12):3066-3075

12. Thounthong $P$, Rael $S$ (2009) The benefits of hybridization. IEEE Ind Electron Mag 3(3):25-37

13. Yang YP, Liu JJ, Wang TJ, Kuo KC, Hsu PE (2007) An electric gearshift with ultracapacitors for the power train of an electric vehicle with a directly driven wheel motor. IEEE Trans Veh Technol 56(5 I):2421-2431

14. Weddell AS, Merrett GV, Kazmierski TJ, Al-Hashimi BM (2011) Accurate supercapacitor modeling for energy harvesting wireless sensor nodes. IEEE Trans Circ Syst II 58(12):911-915

15. Barlev D, Vidu R, Stroeve $P(2011)$ Innovation in concentrated solar power. Sol Energy Mater Sol Cells 95(10):2703-2725

16. Choudhary P, Srivastava RK, Mahendra SN, Motahhir S (2017) Sustainable solution for crude oil and natural gas separation using concentrated solar power technology. In: IOP conference series: materials science engineering, vol 225

17. Pelay U, Luo L, Fan Y, Stitou D, Rood M (2017) Thermal energy storage systems for concentrated solar power plants. Renew Sustain Energy Rev 79:82-100

18. Boussetta M, Motahhir S, El Bachtiri R, Allouhi A, Khanfara M, Chaibi Y (2019) Design and embedded implementation of a power management controller for wind-PVdiesel microgrid system. Int J Photoenergy. https://doi. org/10.1155/2019/8974370

19. Shezan SA et al (2016) Performance analysis of an off-grid wind-PV (photovoltaic)-diesel-battery hybrid energy system feasible for remote areas. J Clean Prod 125:121-132

20. Al-falahi MDA, Jayasinghe SDG, Enshaei H (2017) A review on recent size optimization methodologies for standalone solar and wind hybrid renewable energy system. Energy Convers Manag 143:252-274

21. Castillo-Calzadilla T, Andonegui CM, Gomez-Goiri M, Macarulla AM, Borges CE (2019) Systematic analysis and design of water networks with solar photovoltaic energy. IEEE Trans Eng Manag 99:1-14

22. Uzunoglu M, Onar OC, Alam MS (2009) Modeling, control and simulation of a PV/FC/UC based hybrid power generation system for stand-alone applications. Renew Energy 34(3):509-520

23. Han Y, Chen W, Li Q, Yang H, Zare F, Zheng Y (2019) Two-level energy management strategy for PV-fuel cell-battery-based DC microgrid. Int J Hydrogen Energy 44(35):19395-19404

24. Thounthong P, Luksanasakul A, Koseeyaporn P, Davat B (2013) Intelligent model-based control of a standalone photovoltaic/ 
fuel cell power plant with supercapacitor energy storage. IEEE Trans Sustain Energy 4(1):240-249

25. Ali Djerioui AS, Houari A, Zeghlache S, Hemza Mekki MFFB (2015) Model predictive control based energy management strategy for a plug-in hybrid electric vehicle. In: International conference on applied analysis and mathematical modelling

26. Adzakpa KP, Agbossou K, Dubé Y, Dostie M, Fournier M, Poulin A (2008) PEM fuel cells modeling and analysis through current and voltage transient behaviors. IEEE Trans Energy Convers 23(2):581-591

27. Djerioui A, Houari A, Zeghlache $S$ et al (2019) Energy management strategy of supercapacitor/fuel cell energy storage devices for vehicle applications. Int J Hydrogen Energy 44(41):23416-23428

28. Gemmen RS, Williams MC, Gerdes K (2008) Degradation measurement and analysis for cells and stacks. J Power Sources 184(1):251-259

29. Souleman NM, Tremblay O, Dessaint LA (2009) A generic fuel cell model for the simulation of fuel cell power systems. In: 2009 IEEE power and energy society general meeting, PES '09, pp 1722-1729

30. Motapon SN, Tremblay O, Dessaint LA (2012) Development of a generic fuel cell model: application to a fuel cell vehicle simulation. Int J Power Electron 4(6):505-522

31. Kabalci Y, Kabalci E (2017) Modeling and analysis of a smart grid monitoring system for renewable energy sources. Sol Energy 153:262-275

32. Motahhir S, Chalh A, El Ghzizal A, Sebti S, Derouich A (2017) Modeling of photovoltaic panel by using proteus. J Eng Sci Technol Rev 10(2):8-13

33. Salman S, Ai X, Wu Z (2018) Design of a P-\&-O algorithm based MPPT charge controller for a stand-alone 200W PV system.
Prot Control Mod Power Syst. https://doi.org/10.1186/s4160 1-018-0099-8

34. Chalh A, Motahhir S, El Hammoumi A, El Ghzizal A, Derouich A (2018) Study of a low-cost PV emulator for testing MPPT algorithm under fast irradiation and temperature change. Technol Econ Smart Grids Sustain Energy. https://doi.org/10.1007/s4086 6-018-0047-8

35. Sedlakova $V$ et al (2015) Supercapacitor equivalent electrical circuit model based on charges redistribution by diffusion. J Power Sources 286:58-65

36. Thounthong P, Tricoli P, Davat B (2014) Performance investigation of linear and nonlinear controls for a fuel cell/supercapacitor hybrid power plant. Int J Electr Power Energy Syst 54:454-464

37. Fliess PRM, Levine J, Martin P (1997) Systems and control in the twenty-first century, 1st edn., vol 22. Birkhäuser Boston, Boston, MA

38. Djerioui A, Houari A, Saim A, Mouhhamed A, Surge P, Benkhoris MF (2020) Flatness based grey wolf control for load voltage unbalance mitigation in three-phase four-leg voltage source inverters. IEEE Trans Ind Appl. https://doi.org/10.1109/ TIA.2019.2957966

39. Mesbahi T, Khenfri F, Rizoug N, Bartholomeüs $P$, Le Moigne $P$ (2017) Combined optimal sizing and control of Li-lon battery/ supercapacitor embedded power supply using hybrid particle Swarm-Nelder-Mead Algorithm. IEEE Trans Sustain Energy 8(1):59-73

Publisher's Note Springer Nature remains neutral with regard to jurisdictional claims in published maps and institutional affiliations. 